\title{
Effects of the Perception of Convergence in Sports Industry and Service Differentiation Strategies Grafting Augmented Reality on Viewing Intention
}

\author{
Jung-Heui Oh, Boo-Gil Seok, Jai-Woo Oh, Kwang-Min Cho
}

\begin{abstract}
In a bid to contribute to the continuous growth of Korean Baseball Industry, this study aims to examine the effects of recognizing economic, cultural, international, social attributes of sport convergence industry and service differentiation strategies on viewing intention. Further, based on the findings of this study, applicable strategies for differentiating service of Korean Professional Baseball Industry and also strategic plans and basic data for securing competitive advantages are also provided. This study was conducted among 20-year-old men and women who visited stadium(Korea Professional Baseball Game) during September, 2016. The questionnaire was used and a total of 361 data were obtained. All the data were analyzed utilizing both SPSS and AMOS statistical programs. After coding, confirmatory factor analysis and reliability analysis were carried out. After that, path analysis was also carried out through analysis of correlation between each factor and structural equation model. First, the economic attribute recognition of sports convergence industry had positive effect on the recognition of service differentiation strategies. Second, cultural attribute recognition of sports convergence industry had not a significant effect on recognition of service differentiation strategy. Third, the recognition of international exchanges in sports convergence industry had positive effect on the recognition of service differentiation strategies. Fourth, the recognition of social attributes in the sports convergence industry had not a significant effect on the recognition of service differentiation strategies. Fifth, the analysis of the effect of service differentiation strategy perception on the intention of watching sports showed that service differentiation strategy perceptions had positive influence on audience intention. The subjects of this study were selected as adult men and women in their 20 sho can easily accept new technology. However, since all age groups are participating in sports, it is necessary to study various age groups for the future type of sports industry.
\end{abstract}

Keywords : Perception of Convergence in Sports Industry (economic, cultural, international exchange, social), Service Differentiation Strategies, Augmented Reality (AR), Viewing Intention.

Revised Manuscript Received on July 22, 2019.

Jung-Heui Oh, Department of Sport Industry Studies, Yonsei University, Seoul, Korea. Email: sbaby@yonsei.ac.kr

Boo-Gil Seok, Department of Beauty and Health, Halla University, Seoul, Korea. Email: bgseok@ halla.ac.kr

Jai-Woo Oh, Department of Health Management \& Education, Kyungdong University, Seoul, Korea. Email: sbaby692001@ naver.com

Kwang-Min Cho, Department of Sport Industry Studies, Yonsei University, Seoul, Korea. Email: kwang @yonsei.ac.kr

\section{INTRODUCTION}

Today's flow of industry leads to development of complex technology among various industries through 'convergence', leading to overcoming the low growth limit of existing industries and further finding new growth engines[1]. This wave of fusion is also emerging in the sports industry. Sports convergence industry refers to a form in which the scope and role of the sports industry are expanded through the fusion of various industries, academia, and technology in addition to sports itself(participation and spectator sports), and the results of convergence should coincide with convenience, stability, and usability[2].

Since the launch of the new government in 2013, Korea has been actively encouraging the concept of mutual convergence between various industries and technologies as a core area that will enable the creation economy to be activated at the national level. The vision of creating a new market combining sports, IT, ICT, etc. is presented as a competitive advantage of sports industry through support for the achievement of higher realization expectation and economic value added inducement[3]. However, with the government policy mentioned above, the development of convergence industry may play a positive role in the growth and development of the sports industry, but the government - led policy alone seems to have limited growth. According to previous studies, the establishment of the perception of the industry has an important influence on the process of consumer choice behavior[4]. Based on the AIDA model theory of consumer purchase behavior proposed by Lewis(1898)[5] Various developed consumer behavior models are based on perceptions of consumption behavior[6]. Based on previous studies and theories, it is necessary to measure consumer perception of sports convergence industry.

On the other hand, in the case of professional baseball, which has the highest seat occupancy among the Korean Spectator sports market, the growth of the league industry scale is saturated. Soon there is a risk of slowing down the growth of the market and going the way of the decline of the professional baseball industry in the future[7]. From this point of view, this study suggests a service differentiation strategy for sports that utilizes augmented reality technology as an alternative to overcome the current situation.

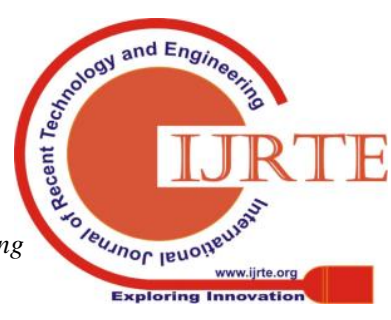


The augmented reality (AR) technology has been able to realize more immersive realization due to the development of ubiquitous computing technology, in 1968 starting with 'Head Mounted 3D display'. Ubiquitous computing technology is evolving into augmented reality technology combined with the wearable direction attached directly to the body and the physical world in which we live[8]. AR is a kind of mixed reality world in which the real world and the virtual world are mixed[9]. It can be said that this technique provides a more immersive and realistic feeling by providing the user with a seamless mixture of real world and virtual world in real time[10]. Therefore, it is an attractive alternative to provide a real-time information to the consumers on the field or to relay experiences based on the augmented reality technology to provide experiences such as watching the actual game at a place other than the scene can be.

The purpose of this study is to investigate the effects of recognizing economic, cultural, international, and social attributes of sport convergence industry and service differentiation strategies on viewing intention. In addition, this study also aims to provide applicable strategies for differentiating service of Korean professional Baseball Industry and also strategic plans and basic data for securing competitive advantages.

\section{RESEARCH MODEL AND HYPOTHESIS}

Based on the necessity and the previous research, this study set up the following hypothesis and research model. In Figure 1

H1. The awareness of economic properties in sports convergence industry will have a positive effect on the recognition of service differentiation strategy with augmented reality.

H2. The awareness of cultural properties in sports convergence industry will positively influence service differentiation strategy with augmented reality.

H3. The awareness of international and cultural properties in sports convergence industry will have a positive effect on service differentiation strategy with augmented reality.

H4. The awareness of social properties in sports convergence industry will have a positive effect on the recognition of service differentiation strategy with augmented reality.

H5. The awareness of service differentiation strategy with augmented reality according to the recognition of sports convergence industry will have a positive effect on the intention to view.

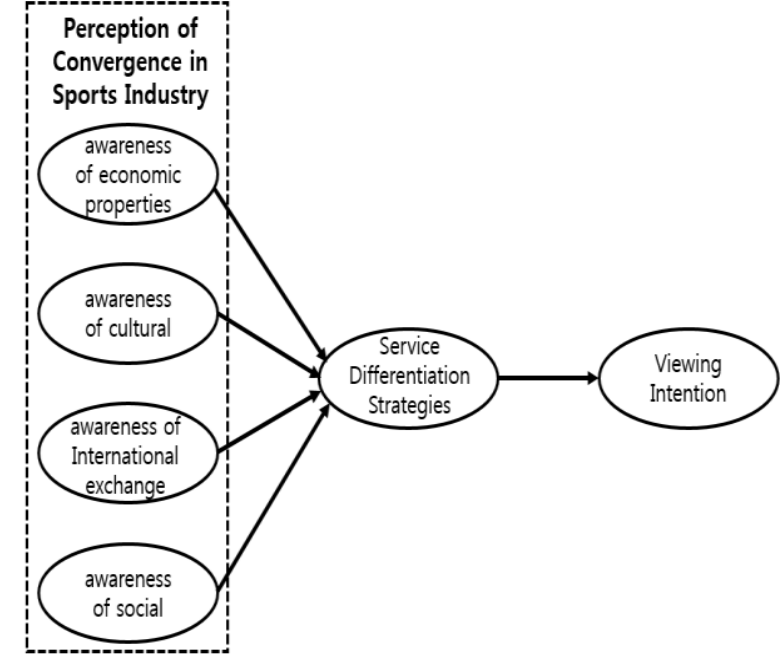

Figure 1: Research Model

\section{DATA ANALYSIS}

This study used a convenient sampling method for non random sampling of 20-year-old men and women who visited stadium (Korea Professional Baseball Game) during September of 2016. The questionnaire was used as a survey tool to accomplish the purpose of this study and self-administration method was used. Out of 370 questionnaires, the last 361 were used for actual data analysis. SPSS 18.0 and AMOS 20.0 statistical programs were used for analyzing collected data.

CFA(Confirmatory Factor Analysis) was used to confirm the single dimensionality of the factors set in this study, and reliability analysis was used to verify the internal consistency of the items by factor. The results are shown in the Table 1.

The fit index for the model evaluation is recommended when the TLI and CFI index are above 0.90 and the RMSEA index is below $0.08[11]$.

In addition, it is judged that there is no problem when CR and AVE, which show fit index of intensive validity, exceed 0.7 and 0.5 , respectively. Cronbach's $\alpha$ value, which is used as index showing internal consistency, is 0.7 or more. It is judged that there is no problem[12]. All the fit indices of this study were confirmed to be normal.

Table 1: Confirmatory Factor Analysis results

\begin{tabular}{|c|c|c|c|c|c|c|}
\hline \multirow{4}{*}{ Factor } & Item & $\begin{array}{c}\text { Standardi } \\
\text { zed } \\
\text { estimate }\end{array}$ & $\begin{array}{c}\text { Error } \\
\text { variance }\end{array}$ & CR & AVE & $\begin{array}{c}\text { Cronbach' } \\
\text { s } \alpha\end{array}$ \\
\hline \multirow{4}{*}{$\begin{array}{c}\text { awareness of } \\
\text { economic }\end{array}$} & A_1 & 0.869 & 0.132 & & & \\
\cline { 2 - 4 } & A_2 & 0.842 & 0.181 & & & \\
\cline { 2 - 4 } & A_4 & 0.652 & 0.400 & 0.911 & 0.675 & 0.865 \\
\cline { 2 - 4 } & A_5 & 0.675 & 0.369 & & & \\
\hline \multirow{2}{*}{$\begin{array}{c}\text { awareness of } \\
\text { cultural }\end{array}$} & B_1 & 0.664 & 0.428 & \multirow{2}{*}{0.902} & 0.650 & 0.859 \\
\cline { 2 - 4 } & B_2 & 0.673 & 0.403 & & & \\
\hline
\end{tabular}




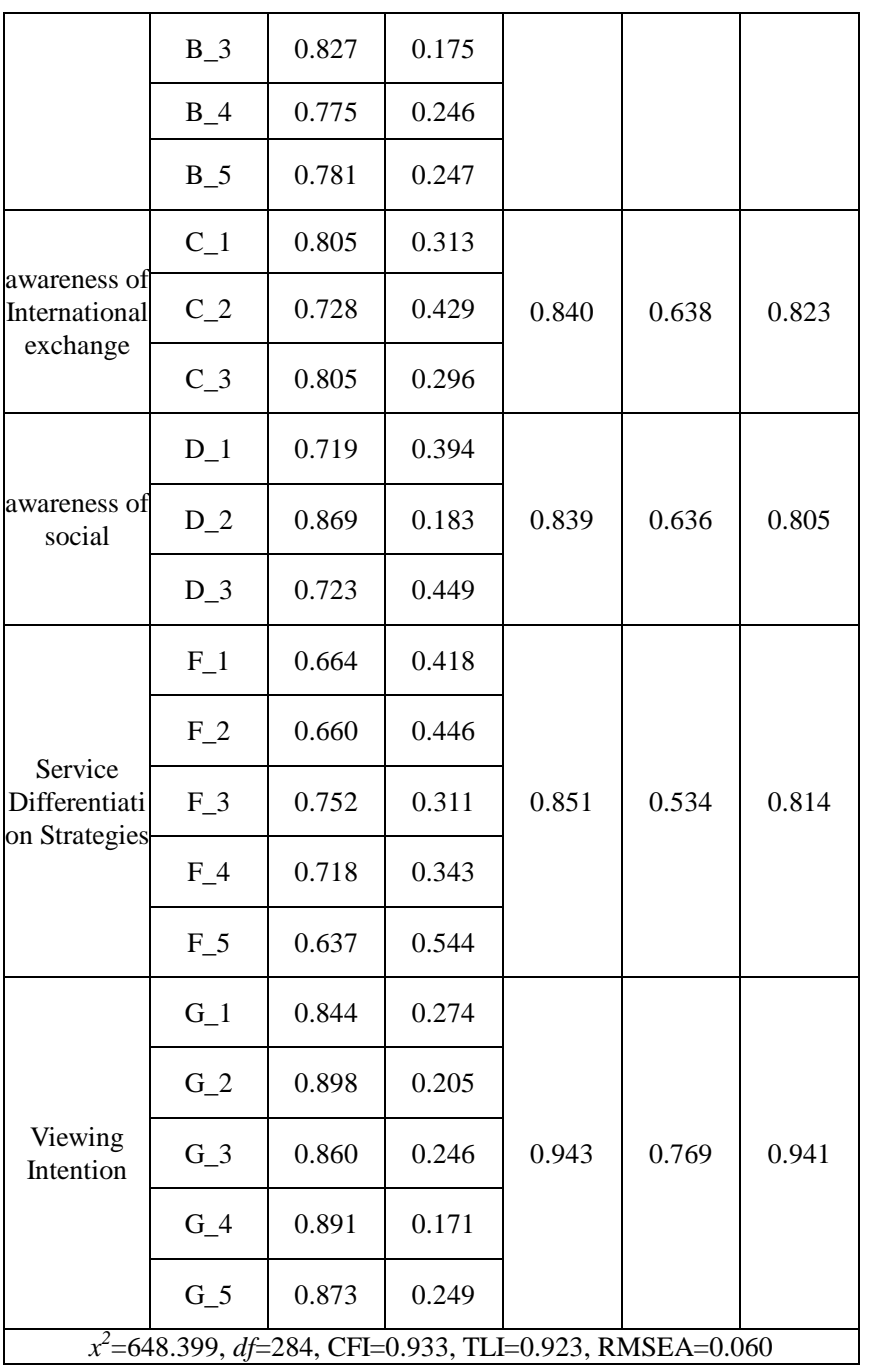

\section{RESULTS}

Step 1 Correlation: Pearson 's correlation coefficient was used to analyze the correlations between the variables. As a result, statistically significant correlation was found between all variables as shown in Table 2 . In addition, the correlation coefficient between all variables was lower than 0.8 , which suggests that there is no problem in multi-collinearity.

Table 2: Correlation

\begin{tabular}{|c|c|c|c|c|c|c|}
\hline & 1 & 2 & 3 & 4 & 5 & 6 \\
\hline $\begin{array}{l}\text { 1. awareness } \\
\text { of economic }\end{array}$ & 1 & & & & & \\
\hline $\begin{array}{l}\text { 2. awareness } \\
\text { of cultural }\end{array}$ & $\begin{array}{c}0.615^{* * *} \\
*\end{array}$ & 1 & & & & \\
\hline $\begin{array}{l}\text { 3. awareness } \\
\text { of } \\
\text { International } \\
\text { exchange }\end{array}$ & $\begin{array}{c}0.435^{* *} \\
*\end{array}$ & $\begin{array}{c}0.479 * \\
* *\end{array}$ & 1 & & & \\
\hline $\begin{array}{l}\text { 4. awareness } \\
\text { of social }\end{array}$ & $\begin{array}{c}0.320^{* * *} \\
*\end{array}$ & $\begin{array}{c}0.349^{*} \\
* *\end{array}$ & $\begin{array}{l}0.606^{*} \\
* *\end{array}$ & 1 & & \\
\hline $\begin{array}{l}\text { 5. Service } \\
\text { Differentiatio } \\
\text { n Strategies }\end{array}$ & $\begin{array}{c}0.323^{* * *} \\
*\end{array}$ & $\begin{array}{c}0.309^{*} \\
* *\end{array}$ & $\begin{array}{c}0.331 * \\
* *\end{array}$ & $\begin{array}{c}0.252^{*} \\
* *\end{array}$ & 1 & \\
\hline $\begin{array}{l}\text { 6. Viewing } \\
\text { Intention }\end{array}$ & $\begin{array}{c}0.291 * * \\
*\end{array}$ & $\begin{array}{l}0.286^{*} \\
* *\end{array}$ & $\begin{array}{c}0.325^{*} \\
* *\end{array}$ & $\begin{array}{c}0.234 * \\
* *\end{array}$ & $\begin{array}{c}0.449^{*} \\
* *\end{array}$ & 1 \\
\hline
\end{tabular}

Step 2 Fit indices for the Research Model: In general, it confirms the suitability of the research model through $\mathrm{x} 2$ verification, but it has the drawback of being sensitive to the sample size. The absolute fit index and incremental fit index TLI, CFI, and RMSEA. The overall fit of the research model is shown in the following Table 3.

Table 3: Fit indices for the Research Model

\begin{tabular}{|c|c|c|c|c|c|c|}
\hline & $x^{2}$ & $d f$ & $p$ & TLI & CFI & RMSEA \\
\hline $\begin{array}{c}\text { Fit } \\
\text { index }\end{array}$ & $\begin{array}{c}661.78 \\
5\end{array}$ & 288 & 0.000 & 0.922 & 0.931 & 0.060 \\
\hline
\end{tabular}

Step 3 Statistical results for structural model: Five hypotheses were set up to examine the relationship between the perception of attributes of sporting convergence industry of Korean professional baseball consumers and the recognition and observation of service differentiation strategies applied to augmented reality, and path analysis was conducted through structural equation . A summary of the measurement results is shown in Table 4.

As a result of $\mathrm{H} 1$, path factor value was $0.205(\mathrm{t}=2.585)$. $\mathrm{H} 1$ was adopted that the factor of recognition of economic attribute of sports convergence industry was positively significant in recognition of service differentiation strategy. $\mathrm{H} 2$ was rejected because it was not statistically significant in the $95 \%$ confidence interval. Therefore, H2 was rejected because it can't be judged that cultural attribute recognition of sports industry affects service recognition strategy recognition. As a result of $\mathrm{H} 3$, the path factor was $0.181(\mathrm{t}=$ 2.097), indicating that the factor of recognition of international exchange attributes of sports convergence industry has a positive influence on recognition of service differentiation strategy. H4 is not statistically significant in the $95 \%$ confidence interval. H4 was rejected because it can't be judged that the social attribute recognition of sports convergence industry affects service recognition strategy recognition. As a result of $\mathrm{H} 5$, the path coefficient was 0.752 $(t=8.057)$, and the factor of service differentiation strategy was analyzed as positive in the intention of viewing. H5 was adopted.

Table 4: Statistical results for structural model

\begin{tabular}{|c|c|c|c|c|c|}
\hline $\begin{array}{c}\text { Hyp } \\
\text { othe } \\
\text { sis }\end{array}$ & Path & $\begin{array}{c}\text { Path } \\
\text { coefficients }\end{array}$ & S.E & $t$-value & Result \\
\hline H1 & $\begin{array}{c}\text { awareness of } \\
\text { economic } \\
\rightarrow \text { Service } \\
\text { Differentiation } \\
\text { Strategies }\end{array}$ & 0.205 & 0.079 & $2.585^{*}$ & $\begin{array}{c}\text { Accep } \\
\text { ted }\end{array}$ \\
\hline $\mathrm{H} 2$ & $\begin{array}{c}\text { awareness of } \\
\text { cultural } \\
\rightarrow \text { Service } \\
\text { Differentiation } \\
\text { Strategies } \\
\end{array}$ & 0.097 & 0.091 & 1.059 & $\begin{array}{c}\text { Reject } \\
\text { ed }\end{array}$ \\
\hline H3 & $\begin{array}{c}\text { awareness of } \\
\text { International } \\
\text { exchange } \\
\rightarrow \text { Service } \\
\text { Differentiation } \\
\text { Strategies } \\
\end{array}$ & 0.181 & 0.086 & $2.097^{*}$ & $\begin{array}{c}\text { Accep } \\
\text { ted }\end{array}$ \\
\hline $\mathrm{H} 4$ & $\begin{array}{c}\text { awareness of } \\
\text { social } \\
\rightarrow \text { Service } \\
\text { Differentiation } \\
\text { Strategies }\end{array}$ & 0.010 & 0.085 & 0.113 & $\begin{array}{c}\text { Reject } \\
\text { ed }\end{array}$ \\
\hline
\end{tabular}


Effects of the Perception of Convergence in Sports Industry and Service Differentiation Strategies grafting augmented reality on Viewing Intention

\begin{tabular}{|c|c|c|c|c|c|}
\hline H5 & $\begin{array}{c}\text { Service } \\
\text { Differentiation } \\
\text { Strategies } \\
\rightarrow \text { Viewing } \\
\text { Intention }\end{array}$ & 0.752 & 0.093 & $8.057^{*}$ & $\begin{array}{l}\text { Accep } \\
\text { ted }\end{array}$ \\
\hline$p<0$ & $p<0.01,{ }^{* * *} p<$ & & & & \\
\hline
\end{tabular}

\section{DISCUSSION AND CONCLUSION}

With the formation of the Korean professional sports league, the Korean sports market has begun to expand. However, Korea's professional baseball, which has the largest number of spectators, is expected to slow down considering the fact that the growth and decline of the market move in a cycle (i.e. the product life cycle). The purpose of this study is to investigate the potentialities of sports convergence industry through convergence with various industrial groups as a measure to rebound sports industry. The conclusion is as follows:

First, the hypothesis that economic and international attribute recognition of sports convergence industry will affect the recognition of service differentiation strategies was accepted. The result showed that the recognition of economic and international attributes has Direction. This suggests that the overall economic benefits and international exchange benefits of the nation given through the sports convergence industry have a causal relationship with the service differentiation strategies recognized by consumers.

Second, the hypothesis that service differentiation strategy perception, which incorporates augmented reality technology, has an influence on viewing intention. Therefore, it is necessary to provide a strategy to enhance positive awareness by enhancing differentiated experiences through high interaction between consumers and viewing experiences by providing new viewing forms that incorporate augmented reality technology or introducing new participatory services.

Finally, in order to expand the sport market for Korean professional baseball, it is necessary to improve the awareness of the sports convergence industry of consumers and the awareness of service differentiation strategies that incorporate the augmented reality.

\section{CONFLICT OF INTEREST}

The authors declare no conflict of interest.

\section{REFERENCES}

1. K. S. Kwon., T. Y. Oh., D. W. Kim., J. W. Oh. "Exploratory Analysis of Sport Industrial Convergence Trend" Korean Journal of Sport Science., 25 (2), 306-317, 2014. https://doi.org/10.24985/kjss.2014.25.2.306.

2. S. H. Lee. "Suggestions for Activation of Sport Convergence Enterprises” Journal of Digital Convergence., 13 (9), 505-513, 2015. https://doi.org/10.14400/JDC.2015.13.9.505.

3. Ministry of Culture, Sports and Tourism. Mid - to Long - Term Development Plan for Sports Industry. 2013.

4. J. H. Lee. "A Study on the Influence of Recognition for Casino Gaming on Attitude and Choice Behavior" The journal of tourism studies., 16, 265-284, 2004.

5. Lewis, E. St. Elmo. The Psychology of Selling and Advertising. New York: McGraw-Hill. 1898.

6. N. Hosono., S. Gotanda., H. Inoue., Y. Tomita. "ATM advertisement and financial preferences with sensory analysis" Human-Computer Interaction. HCI Applications and Services., 4553, 42-47, 2007. https://doi.org/10.1007/978-3-540-73111-5_5.

7. Article title. http://sports.mk.co.kr/view: 03/10/2012.
8. A. L. Jung., M. G. Kim., W. C. Shin., K. H. Lee. "Realization of Multi-User Tangible Non-Glasses Mixed Reality Space” Indian Journal of Science and Technology., 2016.https://doi.org/10.17485/ijst/2016/v9i24/96161.

9. J. H. Kim., Y. M. Kim., M. G. Kim., E. J. Song. "Kidult Contents Development using Mobile Augmented Reality" Indian Journal of Science and Technology., 8(S9), 518-525, 2015. https://doi.org/10.17485/ijst/2015/v8iS9/68325

10. R. T. Azuma. "A survey of augmented reality" In Presence: Teleoperators and Virtual Environment., 6(4), 355-385, 1997. https://doi.org/10.1162/pres.1997.6.4.355.

11. L. T. Hu., P. M. Bentler. "Cutoff criteria for fit indexes in covariance structure analysis: conventional criteria versus new alternatives" $\begin{array}{lllll}\text { Structural Equation } \quad \text { Modeling., } & 6, & 1-55, & 1999 .\end{array}$ https://doi.org/10.1080/10705519909540118.

12. J. C. Nunnally. Psychometric theory(2nd ed.). New York: McGraw-Hill 1978 